Acta Agroph., 2019, 26(3), 5-14

doi: $10.31545 /$ aagr/113241

\title{
YIELDS OF OILSEED RAPE IN HABITAT CONDITIONS OF PODKARPACKIE PROVINCE
}

\author{
Wacław Jarecki@, Dorota Bobrecka-Jamro @ \\ Department of Plant Production, Faculty of Biology and Agriculture, Rzeszów University \\ ul. Zelwerowicza 4, 35-601 Rzeszów, Poland \\ e-mail: waclaw.jarecki@wp.pl
}

\begin{abstract}
A b stract: The objective of the study was the estimation of yields of winter oilseed rape, cultivar Visby $F_{1}$, in diversified habitat conditions of the Podkarpackie Province. The study showed that the average seed yield of winter oilseed rape amounted to $3.97 \mathrm{t} \mathrm{ha}^{-1}$. The highest yields of oilseed rape were obtained in Przecław and Skołoszów. Yields obtained in Boguchwała were significantly lower, but only in relation to those obtained in Przecław. The lowest yields of oilseed rape were obtained in Nowy Lubliniec. Oilseed rape plants attained technical ripeness the earliest in Przecław and Nowy Lubliniec, as compared to those grown in Skołoszów and Boguchwała. In the years of the study oilseed rape plants did not suffer from frost bite, the poorest overwintering being noted in Przecław. Infestation with black spot of cruciferous plants was at similar levels in the particular localities. Fat content in the seeds did not depend significantly on the habitat conditions. The highest fat yield per hectare was obtained in Przecław, significantly lower in Skołoszów and Boguchwała, and the lowest in Nowy Lubliniec. Overwintering of oilseed rape plants was the poorest in the season of 2015/2016, but in spite of that the yield of seeds amounted to $4.07 \mathrm{t} \mathrm{ha}^{-1}$. In the analysed years, oilseed rape plants attained their technical ripeness phase on similar dates. In 2015 fat content in seeds was the highest, nut fat yield per hectare was the lowest. In that year, the lowest level of infestation with black spot of coniferous plants was noted. On average, the highest seed yield and fat yield was obtained in 2017.

Keywords: Brassica napus L. ssp. oleifera Metzg., soil-climate conditions, crude fat, seed yield, fat yield
\end{abstract}

\section{INTRODUCTION}

Oilseed rape (Brassica napus L. ssp. oleifera Metzg.) is the most important oil bearing plant in Poland. In its cultivation, the winter form dominates over the spring form, mainly due to to higher yields. Statistical data (GUS, 2018) show that the average yields of oilseed rape in Poland amount to less than $3 \mathrm{t} \mathrm{ha}^{-1}$. Whereas, the yielding potential of oilseed rape is considerably higher, but not always achieved in agricultural 
practice (Bobrecka-Jamro et al. 2013). The level and quality of oilseed rape yields are affected by the cultivar (Weber et al. 2003, Bujak et al. 2008, Novickiene et al. 2010), cultivation technology (Kotecki et al. 2004, Wójtowicz 2004, Bartkowiak-Broda et al. 2005, Wielebski 2009a), and by the habitat conditions (Kaczmarek et al. 2003, Latusek and Bujak 2012). In the case of winter oilseed rape, the choice of cultivars is extensive, and the cultivation technology is well known and usually conducted at the intensive level (Jarecki et al. 2013, Hoppe and Wenda-Piesik 2018). Contemporary breeding of winter oilseed rape is aimed at the acquisition of cultivars with a high yielding potential and characterised by a high capacity for adaptation to diverse soil and climate conditions (Szała et al. 2015). Therefore, for cultivation one should select cultivars that are high yielding and tested in the given habitat conditions. The choice of cultivars is aided by published lists of cultivars recommended for a given province. Latusek and Bujak (2012) and Bujak et al. (2008) note that individual cultivars respond differently to the high level of cultivation technology, and in addition that is related to the interactions with particular localities and years of experiments. Studies conducted so far (Latusek and Bujak 2012, Kulig et al. 2012, Wójtowicz 2013, Skwaryło-Bednarz and Kotecki 2014) indicate that oilseed rape produces high yields, but in better soil-climate conditions. In less favourable conditions, oilseed rape yields are usually low. Weber et al. (2003) observed that genetic variation of cultivars becomes more apparent on better soils (class II or III), while on lighter soils the yields of the various cultivars are more uniform. Kaczmarek et al. (2003) and Ostovari et al. (2019) maintain that the diversified response of winter oilseed rape cultivars to changes in the soil-climate environment indicates the need for testing cultivars in many different environments to determine the kind of genotype-environment interaction.

The objective of the study was the comparison of yielding of a hybrid winter oilseed rape cultivar, Visby $F_{1}$, in relation to the diversified habitat conditions of the Podkarpackie Province.

\section{MATERIAL AND METHOD}

In the seasons of 2014/2015-2016/2017 a strict field experiment was set up, with winter oilseed rape $\mathrm{cv}$. Visby $\mathrm{F}_{1}$. The experiment was conducted at four localities in the Podkarpackie Province, at the variety testing experimental stations in Przecław (SDOO Przecław), Skołoszów (ZDOO Skołoszów), Nowy Lubliniec (ZDOO Nowy Lubliniec), and at the Podkarpacki Agricultural Advisory Centre in Boguchwała (PODR w Boguchwale). In Przecław, Skołoszów and Nowy Lubliniec the experiments were conducted within the framework of Post-registry Variety Testing.

The experiment was a single-factor one, conducted in four replicates. The hybrid cultivar Visby $F_{1}$ (Saaten Union Polska Sp. z o.o.) is suitable for cultivation in the Podkarpackie Province and produces a high and stable seed yield. The 
humidity and temperature conditions are given according to the records from the Meteorological Station of the PODR in Boguchwała and from the Meteorological Stations of SDOO Przecław, ZDOO Skołoszów and ZDOO Nowy Lubliniec. Analysis of soil samples was performed at the accredited laboratory of the Regional Agricultural Chemical Station in Rzeszów, according to Polish standards. The soil conditions in which the experiment was conducted are presented in Table 1.

Table 1. Soil conditions (average for the years)

\begin{tabular}{|c|c|c|c|c|}
\hline Parameter & $\begin{array}{c}\text { PODR } \\
\text { Boguchwała }\end{array}$ & $\begin{array}{c}\text { SDOO } \\
\text { Przecław }\end{array}$ & $\begin{array}{c}\text { ZDOO } \\
\text { Skołoszów }\end{array}$ & $\begin{array}{c}\text { ZDOO } \\
\text { Nowy Lubliniec }\end{array}$ \\
\hline Agronomic category of soil & medium & medium & heavy & light \\
\hline Soil suitability complex & good wheat & good wheat & very good wheat & good rye \\
\hline Soil quality class & IIIa & IIIa & II & IVa \\
\hline Soil $\mathrm{pH}$ in $1 \mathrm{M} \mathrm{KCl}$ & 6.24 & 6.84 & 6.42 & 6.65 \\
\hline $\operatorname{mg} 100 \mathrm{~g}^{-1}$ & 18.3 & 18.7 & 19.6 & 19.0 \\
\hline IIIg $100 \mathrm{~g}$ & 22.7 & 20.3 & 26.4 & 16.3 \\
\hline $\mathrm{Mg}$ & 7.5 & 8.3 & 9.6 & 6.6 \\
\hline
\end{tabular}

Oilseed rape cultivation was conducted in conformance with the methodology developed by the Research Centre for Cultivar Testing in Słupia Wielka. The surface area of an individual plot was $15 \mathrm{~m}^{2}$. Row spacing was $25 \mathrm{~cm}$, and sowing depth was $1.5-2 \mathrm{~cm}$. The adopted sowing rate per unit of surface area was 50 seeds $\mathrm{m}^{-2}$. The preceding crop was winter or spring cereals. Sowing was performed in the third decade of August. NPKMgS fertilisation was applied prior to sowing, at doses dependent on soil quality. In spring, before the start of vegetation, nitrogen fertilisation was applied (in ammonium form) $100 \mathrm{~N} \mathrm{~kg} \mathrm{ha}^{-1}(20 \mathrm{BBCH})$, and in the phase of bud formation (in nitrate form) $70 \mathrm{~N} \mathrm{~kg} \mathrm{ha}^{-1}(51 \mathrm{BBCH})$. In the course of vegetation, the plants were given supplemental fertilisation with a multi-component foliar-application fertiliser (PLONVIT RZEPAK: nitrogen, magnesium, sulphur and microelements). Weeds, diseases and pests were controlled throughout the vegetation season with the use of chemical plant protection agents applied in accordance to manufacturer's recommendations given on the label.

Plant overwintering (\%) was calculated from the difference in the number of plants on the plot before winter and after the start of vegetation in spring. Infestation with black spot of cruciferous plants is given in the scale of $1-9^{\circ}$, where 9 denotes absence of the phenomenon. Estimation was conducted at the moment of the highest intensity of the disease on the leaves and pods. Technical ripeness is specified in the number of days from sowing to attaining the phase $87 \mathrm{BBCH}$.

Seed harvest was conducted in a single stage, in the phase of full ripeness, in the second or third decade of July. Seed yield from a plot was converted to the area of 1 ha, adopting seed moisture as 9\% DM. Fat content in the seeds was determined with the Soxhlet method. The biological yield of crude fat per unit of surface area was calculated on the basis of the value of seed yield and of the seed content 
of fat. The results obtained were processed statistically by means of the analysis of variance. Significance of differences between mean values was tested on the basis of Tukey's semi-intervals of confidence, at significance level of $\alpha=0.05$. The calculations were made using the statistical software ANALWAR-5.3.FR.

\section{RESULTS AND DISCUSSION}

In Boguchwała, Przecław and Skołoszów, the highest precipitation total was noted in the season of 2016/2017, and the lowest in the season of 2014/2015 (Tables 2, 3, 4). In Nowy Lubliniec, the highest precipitation total was noted in the season of 2015/2016 and the lowest in the season of 2016/2017. Mean air temperatures were the highest in the season of 2015/2016, and the lowest in the season of 2016/2017. In 2015, oilseed rape sowing and emergence were hindered due to little rainfalls. In the autumn of each year, air temperatures decreased gradually, which had a beneficial effect on plant hardening before the winter. In the analysed vegetation seasons, the course of weather conditions during the winter period was favourable, the poorest overwintering being noted in Przecław. Seed harvest was generally conducted in favourable weather conditions. Only in July 2016 seed harvest was more difficult in Przecław, due to intensive rains.

Table 2. Weather conditions in the season of 2014/2015

\begin{tabular}{|c|c|c|c|c|c|c|c|c|}
\hline \multirow[b]{2}{*}{ Month } & \multicolumn{4}{|c|}{ Precipitation totals (mm) } & \multicolumn{4}{|c|}{ Mean air temperatures $\left({ }^{\circ} \mathrm{C}\right)$} \\
\hline & 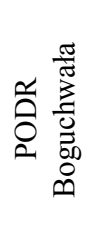 & 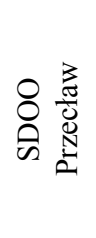 & 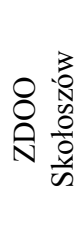 & 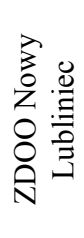 & 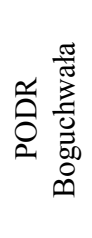 & $\begin{array}{l}\text { 芯 } \\
\text { D } \\
\text { N } \\
0 \\
0 \\
0 \\
0 \\
0\end{array}$ & $\begin{array}{l}3 \\
0 \\
0 \\
0 \\
0 \\
0 \\
0 \\
0 \\
0 \\
0 \\
0 \\
0 \\
0\end{array}$ & 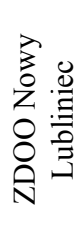 \\
\hline VIII & 65 & 102 & 72 & 102 & 18.8 & 17.6 & 18.6 & 18.3 \\
\hline IX & 49 & 40 & 42 & 45 & 15.0 & 14.5 & 15.2 & 14.3 \\
\hline $\mathrm{X}$ & 36 & 33 & 38 & 41 & 9.7 & 9.4 & 10.4 & 9.6 \\
\hline XI & 9 & 9 & 18 & 22 & 5.4 & 5.4 & 5.4 & 4.7 \\
\hline XII & 26 & 30 & 28 & 33 & 1.1 & 0.6 & 1.5 & 0.5 \\
\hline I & 37 & 34 & 39 & 42 & 0.7 & 1.0 & 0.8 & 0.2 \\
\hline II & 12 & 9 & 12 & 13 & 1.4 & 0.2 & 0.7 & 0.5 \\
\hline III & 40 & 44 & 33 & 47 & 4.4 & 4.4 & 5.3 & 4.2 \\
\hline IV & 31 & 25 & 24 & 49 & 8.8 & 8.3 & 8.7 & 7.6 \\
\hline $\mathrm{V}$ & 92 & 110 & 64 & 96 & 13.1 & 12.4 & 13.1 & 12.4 \\
\hline VI & 9 & 30 & 20 & 12 & 17.9 & 16.5 & 17.8 & 16.9 \\
\hline VII & 65 & 100 & 114 & 86 & 20.5 & 19.7 & 20.4 & 19.6 \\
\hline Total & 471 & 566 & 504 & 588 & 9.7 & 9.2 & 9.8 & 9.1 \\
\hline
\end{tabular}

Wójtowicz (2005) reports that the environmental conditions have the strongest impact on the level of oilseed rape seed yields, since the environment affects the main yield components to a greater degree than nitrogen fertilisation and the 
cultivar. Wójtowicz (2004) observed that the primary factor limiting the yielding of individual winter oilseed rape cultivars is rainfalls. In the aspect in question, Bocianowski et al. (2017) demonstrated a higher productivity of selected hybrid cultivars of oilseed rape, as well as their better adaptation to variable environmental conditions, especially drought. Chmura et al. (2016) demonstrated that the weather conditions also have an impact on the quality of oilseed rape seeds. Optimal for fat

Table 3. Weather conditions in the season of 2015/2016

\begin{tabular}{|c|c|c|c|c|c|c|c|c|}
\hline \multirow[b]{2}{*}{ Month } & \multicolumn{4}{|c|}{ Precipitation totals (mm) } & \multicolumn{4}{|c|}{ Mean air temperatures $\left({ }^{\circ} \mathrm{C}\right)$} \\
\hline & 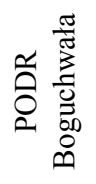 & 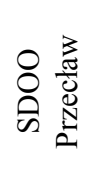 & 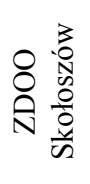 & 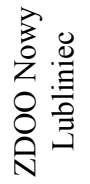 & 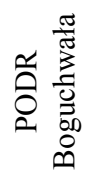 & 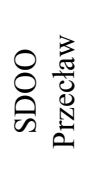 & 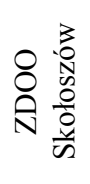 & 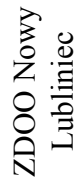 \\
\hline VIII & 22 & 8 & 14 & 13 & 22.3 & 21.0 & 21.2 & 21.3 \\
\hline IX & 56 & 92 & 62 & 72 & 15.7 & 14.8 & 16.6 & 15.7 \\
\hline $\mathrm{X}$ & 38 & 50 & 41 & 55 & 7.6 & 7.1 & 7.8 & 7.3 \\
\hline XI & 110 & 64 & 58 & 74 & 5.3 & 4.9 & 5.8 & 4.8 \\
\hline XII & 15 & 15 & 9 & 17 & 3.1 & 3.2 & 4.9 & 2.8 \\
\hline I & 31 & 32 & 27 & 55 & 2.9 & -2.6 & -2.8 & -3.9 \\
\hline II & 65 & 78 & 59 & 51 & 4.1 & 4.0 & 5.0 & 3.8 \\
\hline III & 39 & 39 & 38 & 35 & 4.5 & 4.7 & 4.7 & 4.1 \\
\hline IV & 59 & 55 & 54 & 77 & 9.8 & 9.8 & 10.4 & 9.9 \\
\hline $\mathrm{V}$ & 34 & 42 & 33 & 63 & 13.9 & 14.1 & 13.9 & 13.6 \\
\hline VI & 39 & 24 & 31 & 56 & 18.7 & 18.6 & 18.4 & 18.4 \\
\hline VII & 103 & 152 & 110 & 99 & 19.2 & 19.0 & 20.0 & 19.4 \\
\hline Total & 611 & 651 & 536 & 667 & 10.1 & 9.9 & 10.5 & 9.8 \\
\hline
\end{tabular}

Table 4. Weather conditions in the season of 2016/2017

\begin{tabular}{|c|c|c|c|c|c|c|c|c|}
\hline \multirow[b]{2}{*}{ Month } & \multicolumn{4}{|c|}{ Precipitation totals (mm) } & \multicolumn{4}{|c|}{ Mean air temperatures $\left({ }^{\circ} \mathrm{C}\right)$} \\
\hline & 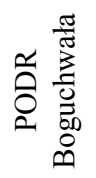 & 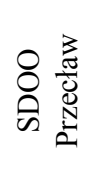 & 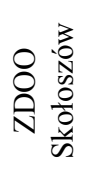 & 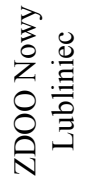 & 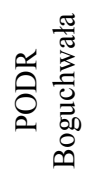 & 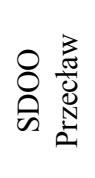 & 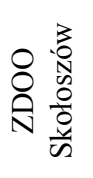 & 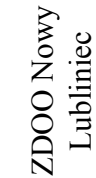 \\
\hline VIII & 59 & 68 & 57 & 38 & 17.9 & 17.6 & 18.7 & 18.3 \\
\hline IX & 40 & 45 & 72 & 40 & 15.4 & 14.7 & 15.9 & 15.0 \\
\hline $\mathrm{X}$ & 119 & 91 & 154 & 96 & 7.5 & 7.2 & 7.5 & 6.9 \\
\hline XI & 36 & 98 & 67 & 49 & 3.5 & 3.6 & 3.2 & 2.3 \\
\hline XII & 50 & 33 & 34 & 47 & -0.7 & 0.6 & 0.2 & -1.2 \\
\hline I & 4 & 14 & 16 & 23 & -6.0 & -6.2 & -5.1 & -7.2 \\
\hline II & 28 & 21 & 26 & 29 & 0.3 & -0.3 & -0.5 & -1.1 \\
\hline III & 37 & 38 & 30 & 31 & 6.2 & 5.9 & 6.4 & 5.7 \\
\hline IV & 55 & 78 & 43 & 37 & 8.2 & 7.5 & 8.7 & 7.5 \\
\hline $\mathrm{V}$ & 86 & 112 & 68 & 41 & 13.5 & 13.7 & 13.4 & 12.8 \\
\hline VI & 41 & 42 & 49 & 45 & 18.4 & 18.7 & 18.1 & 17.9 \\
\hline VII & 95 & 44 & 43 & 78 & 18.7 & 18.4 & 18.7 & 18.6 \\
\hline Total & 650 & 684 & 659 & 554 & 8.6 & 8.5 & 8.8 & 8.0 \\
\hline
\end{tabular}


accumulation in seeds are high rainfalls in the period of December-March, in April and May, with the accompanying higher air temperatures. In turn, lower rainfalls and lower temperature in those periods lead to higher protein content in seeds.

The average seed yield of winter oilseed rape in the experiment was $3.97 \mathrm{tha}^{-1}$ (Table 5). The highest oilseed rape yields were obtained in Przecław and Skołoszów. Seed yield in Boguchwała was significantly lower than that obtained in Przecław. Significantly the lowest was the seed yield obtained in Nowy Lubliniec. The mean seed yield difference between Przecław and Nowy Lubliniec was $1.92 \mathrm{t} \mathrm{ha}^{-1}$. The weather conditions modified oilseed rape yields in the analysed years. In 2015 the yield was the lowest, while in 2017 the highest. The difference between those years was $1.14 \mathrm{t} \mathrm{ha}^{-1}$. It should be mentioned that in Skołoszów high seed yields were obtained in 2016, and in the other localities in 2017.

Table 5. Oilseed rape seed yields $\left(\mathrm{tha}^{-1}\right)$

\begin{tabular}{lcccc}
\hline \multicolumn{1}{c}{ Locality } & 2015 & 2016 & 2017 & Mean \\
\hline PODR Boguchwała & 3.22 & 4.11 & 4.85 & 4.06 \\
SDOO Przecław & 3.58 & 5.12 & 5.32 & 4.67 \\
ZDOO Skołoszów & 3.68 & 4.88 & 4.58 & 4.38 \\
ZDOO Nowy Lubliniec & 2.90 & 2.16 & 3.20 & 2.75 \\
LSD $_{0.05}$ & 0.28 & 0.56 & 0.62 & 0.48 \\
Mean & 3.35 & 4.07 & 4.49 & 3.97 \\
\hline
\end{tabular}

Kaczmarek et al. (2003) and Skwaryło-Bednarz and Kotecki (2014), conducting studies on winter oilseed rape, found that the yields of the individual cultivars depended to a greater extent on the atmospheric conditions than on the potential productivity of soils. Also Kulig et al. (2012) report that the yielding of oilseed rape is strongly dependent on habitat conditions. Those authors obtained significantly higher yields of seeds of winter oilseed rape in better habitat conditions (Głubczyce), in relation to less favourable conditions (Pawłowice). Yields of oilseed rape seeds in the experiment conducted by the cited authors oscillated in the range of 5.37$5.92 \mathrm{t} \mathrm{ha}^{-1}$. In another study, Kulig et al. (2010) demonstrated that the seed yield of population cultivars of oilseed rape is strongly dependent on habitat conditions, and additionally on the interaction of cultivars and years of study. Seed yields obtained by those authors ranged from 2.18 to $7.08 \mathrm{t} \cdot \mathrm{ha}^{-1}$. Wójtowicz and Czernik-Kołodziej (2003) report that the difference between the highest and the lowest yielding cultivar of winter oilseed rape can amount to over $20 \%$. Gehringer et al. (2007) observed that in poorer soil conditions hybrid cultivars of oilseed rape, that uptake nutrients from the soil more effectively, will be more suitable for cultivation.

There was relatively little variation in the run of vegetation of winter oilseed rape plants in the localities under study. Technical ripeness of the plants was noted earlier in Przecław and Nowy Lubliniec, compared to Skołoszów and Boguchwała. In the years of the study, oilseed rape plants entered that development phase on a similar date. Overwintering of the plants was the poorest in Przecław, which has 
been proven statistically. In spite of that, seed yields in that locality were satisfactory. This indicates a high regeneration-compensation capacity of oilseed rape plants. The worst year in terms of oilseed rape plants overwintering was 2016. Infestation with black spot of cruciferous plants was at a fairly stable level in the localities under study. A lower intensity of the diseases was noted in 2015, compared to 2016 and 2017. Fat content in seeds did not depend significantly on the habitat conditions. The highest fat content was determined in seed from the harvest of 2015. Fat yield per hectare was the highest in Przecław. Lower values were obtained in Skołoszów and Boguchwała, and the lowest in Nowy Lubliniec. Fat yield levels varied in the years of the study. The highest fat yields were produced by oilseed rape in 2017, and the lowest in 2015. The difference in fat yields between those years was $511.4 \mathrm{~kg} \mathrm{ha}^{-1}$ (Table 6).

Table 6. Comparison of selected results in the localities and years of the study (mean)

\begin{tabular}{|c|c|c|c|c|c|}
\hline 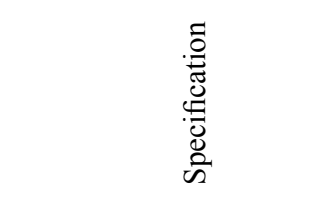 & 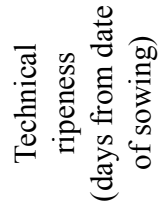 & 离 & 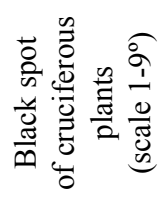 & 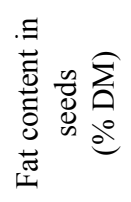 & 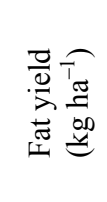 \\
\hline PODR Boguchwała & 314 & 89.0 & 7.8 & 47.4 & 1924.4 \\
\hline SDOO Przecław & 310 & 75.7 & 7.9 & 48.5 & 2265.0 \\
\hline ZDOO Skołoszów & 313 & 95.7 & 8.0 & 47.6 & 2084.9 \\
\hline ZDOO Nowy Lubliniec & 310 & 98.3 & 7.9 & 48.0 & 1320.0 \\
\hline $\operatorname{LSD}_{0.05}$ & n.s. & 11.33 & n.s. & n.s. & 172.38 \\
\hline $2014 / 2015$ & 313 & 93.3 & 8.6 & 48.8 & 1634.8 \\
\hline $2015 / 2016$ & 311 & 85.8 & 7.6 & 47.0 & 1912.9 \\
\hline $2016 / 2017$ & 312 & 90.0 & 7.5 & 47.8 & 2146.2 \\
\hline
\end{tabular}

n.s. - not significant

In a study by Wielebski (2009a), the morphological features of plants before the harvest and the elements of the yield structure were dependent primarily on the habitat conditions and on the genetic traits of the cultivars, and only to a small degree on the level of cultivation technology. Wójtowicz (2005) reports that in the conditions of long-term water deficit, the yields of winter oilseed rape were significantly correlated with the number of plants on a unit of surface area and with the number of seeds in a pod. Whereas, with a uniform distribution of rainfalls in the period of spring-summer vegetation of plants, a significant correlation was found between the yield and the number of seeds in a pod.

A study by Wójtowicz and Czernik-Kołodziej (2003) shows that the yields of fat and protein of winter oilseed rape depend mainly on seed yield, and not on the content of those components in the seeds. In the aspect in question, Nogala-Kałucka et al. (2002) report that seeds of oilseed rape acquired from various cultivars and regions did not differ much in terms of their content of fat which was determined, 
on average, at the level of $42 \%$ DM. In turn, the content of protein in seed samples from various regions, and also from selected cultivars, oscillated at the level of 19.3$21.7 \%$ DM. Wielebski (2009b) demonstrated that seeds of the analysed forms of oilseed rape grown in Łagiewniki, compared to seeds from Zielęcin, had a significantly higher content of fat (by 4.2 percentage points), and a lower content of protein (by 2 percentage points). Tańska and Rotkiewicz (2003) point out that the quality of oilseed rape seeds after harvest is determined by factors related with the post-harvest processing, and especially seed cleaning, drying and storage. They can cause such a deterioration in the technological quality of seeds that they can be considered as the critical points in the production or oilseed rape as an oil-bearing raw material.

\section{CONCLUSIONS}

1. The average seed yield of winter oilseed rape was $3.97 \mathrm{tha}^{-1}$. The highest yields were obtained in Przecław and Skołoszów. In Boguchwała the yield was lower than in Przecław, and the lowest yield was obtained in Nowy Lubliniec. The effect of soil conditions on the yielding of winter oilseed rape was evident especially in years with favourable weather conditions.

2. Oil seed rape plants attained their technical ripeness earlier in Przeclaw and Nowy Lubliniec, relative to plants grown in Skołoszów and Boguchwała. The highest losses of plants after the winter were noted in Przecław. Infestation with black spot of cruciferous plants was at similar levels in all localities.

3. Fat content in seeds was not significantly modified by the habitat conditions. The highest fat content was obtained in Przecław, and the lowest in Nowy Lubliniec.

4. The poorest overwintering of plants was noted in the season of 2015/2016. In 2015 the yields of seeds and fat were the lowest, and in 2017 the highest. In 2015 the highest level of infestation with black spot of cruciferous plants was noted, and the highest fat content in seeds was determined. Plants of winter oilseed rape attained the phase of technical ripeness on similar dates in the years of the study.

Conflict of interest: The Authors does not declare conflict of interest.

\section{REFERENCES}

Bartkowiak-Broda I., Włakowski T., Ogrodowczyk M., 2005. Natural and agrotechnical possibilities of controlling the quality of oilseed rape seeds (in Polish). Pamiętnik Puławski, 139, 7-24.

Bobrecka-Jamro D., Romaniak M., Jarecki W., Buczek J., 2013. Progress in biology and its importance in oilseed rape production in Poland and in the Podkarpackie Province (in Polish). Rośliny oleiste - Oilseed Crops, 34(1), 37-45, https://doi.org/10.5604/12338273.1083017

Bocianowski J., Liersch A., Nowosad K., Bartkowiak-Broda I., 2017. Variability of the agronomic characters in different types of cultivars of winter oilseed rape (Brassica napus L.). Polish J. Agron., 29, 3-11. 
Bujak H., Jedyński S., Kaczmarek J., Kotecki A., 2008. Estimation of stability of yields of population and hybrid cultivars of winter oilseed rape (in Polish). Biuletyn IHAR, 250, 261-271.

Chmura K., Dzieżyc H., Piotrowski M., 2016. The effect of meteorological conditions on fat and protein content in seeds of winter oilseed rape (in Polish). Acta Agroph., 23(2), 163-173.

Gehringer A., Snowdon R., Spiller T., Basunada P., Friedt W., 2007. New oilseed rape (Brassica napus) hybrids with high levels of heterosis for seed yield under nutrient-poor conditions. Breeding Science, 57, 315-320, https://doi.org/10.1270/jsbbs.57.315

GUS. 2018. Statistical Yearbook of Agriculture 2018 (in Polish). Warszawa.

Hoppe Sz., Wenda-Piesik A., 2018. Profitability of winter oilseed rape cultivation in the standard and the high-outlay technology in the conditions of the Kujawsko-Pomorskie Province (in Polish). Zagadnienia Doradztwa Rolniczego, 3, 77-88.

Jarecki W., Bobrecka-Jamro D., Noworól M., 2013. Yield of winter oilseed rape cultivars depending on intensity of cultivation practices. Acta Sci. Pol., Agricultura, 12 (1), 25-34.

Kaczmarek J., Kotecki A., Kotowicz L., Weber R., 2003. Genotype-environmental interaction of yielding of winter oilseed rape in PDO experiments (in Polish). Biuletyn IHAR, 226/227, 2, 395-403.

Kotecki A., Kozak M., Malarz W., 2004. The effect of diversified levels of cultivation technology on the growth and yielding of winter oilseed rape cultivars (in Polish). Rośliny Oleiste - Oilseed Crops, 25(1), 97-107.

Kulig B., Oleksy A., Pyziak K., Styrc N., Staron J., 2010. The effect of habitat conditions on the yields and on the variation of selected plant indices of population cultivars of winter oilseed rape (in Polish). Rośliny Oleiste - Oilseed Crops, 31(1), 99-114.

Kulig B., Oleksy A., Pyziak K., Styrc N., Staron J., 2012. The effect of habitat conditions on the yields and on the values of selected vegetation indices of restored cultivars of winter oilseed rape (in Polish). Fragm. Agron., 29(1), 83-92.

Latusek A., Bujak H., 2012. Estimation of yielding stability of winter oilseed rape cultivars in diversified soil-climate conditions of Lower Silesia on the basis of post-registry experiments (in Polish). Biuletyn IHAR, 265, 59-70.

Nogala-Kałucka M., Goglewski M., Jaworek M., Siger A., Szulczewska A., 2002. Determination of certain components as indicators of quality of oilseed rape seeds produced in various regions of Poland (in Polish). Rośliny Oleiste, 23, 447-459.

Novickienė L., Gavelienė V., Miliuvienė L., Kazlauskienė D., Pakalniškytė L., 2010. Comparison of winter oilseed rape varieties: cold acclimation, seed yield and quality. Žemdirbystè-Agriculture, 97(3), 77-86.

Ostovari Y., Honarbakhsh A., Sangoony H., Zolfaghari F., Maleki K., Ingram B., 2019. GIS and multi-criteria decision-making analysis assessment of land suitability for rapeseed farming in calcareous soils of semi-arid regions. Ecol. Indic., 103, 479-487, https://doi.org/10.1016/j. ecolind.2019.04.051

Skwaryło-Bednarz B., Kotecki A., 2014. Variability of yields and of quality traits of winter oilseed rape cultivars in the natural conditions of Lower Silesia (in Polish). Zeszyty Naukowe Uniwersytetu Przyrodniczego we Wrocławiu. Rolnictwo. CX, 606, 33-48.

Szała L., Cegielska-Taras T., Adamska E., Kaczmarek Z., 2015. Estimation of the genotype-environmental interaction of seed yields of winter oilseed rape population line $\mathrm{DH}$ obtained from $\mathrm{F}_{1}$ hybrids of inverse cross-breeding (in Polish). Rośliny Oleiste - Oilseed Crops, 36(1), 97-114.

Tańska M., Rotkiewicz D., 2003. The effect of various factors on the quality of oilseed rape seeds (in Polish). Rośliny Oleiste - Oilseed Crops, 24, 595-616. 
Weber R., Kaczmarek J., Kotecki A., 2003. The effect of the environment on the variation of yields of winter oilseed rape cultivars in the conditions of Lower Silesia (in Polish). Rośliny Oleiste Oilseed Crops, 24(2), 395-403.

Wielebski F., 2009a. Response of various breeding types of winter oilseed rape cultivars to the level of intensity of cultivation technology. I. Characterisation of ripening plants of oilseed rape and its yields and system of yield-forming elements (in Polish). Rośliny Oleiste - Oilseed Crops, 30(1), 75-90.

Wielebski F., 2009b. Response of various breeding types of winter oilseed rape cultivars to the level of intensity of cultivation technology. II. Quality of harvested yields (in Polish). Rośliny Oleiste - Oilseed Crops, 30(1), 91-101.

Wójtowicz M., 2004. The effect of nitrogen fertilisation and habitat conditions on the biological and utility characteristics of complex hybrid cultivars of winter oilseed rape of the regions of Kaszuby and Mazury (in Polish). Rośliny Oleiste - Oilseed Crops, 25(1), 109-124.

Wójtowicz M., 2005. The effect of environmental conditions on the variation and correlation between seed yield of winter oilseed rape and the components of its structure (in Polish). Rośliny Oleiste - Oilseed Crops, 26(1), 99-110.

Wójtowicz M., 2013. The role of environmental and agrotechnical factors in the shaping of the level and quality of yields of winter oilseed rape (Brassica napus L.) (in Polish). Monografie i rozprawy naukowe 45/2013. IHAR-PIB. Radzików. - Monograph.

Wójtowicz M., Czernik-Kołodziej K., 2003. Response of registered cultivars of winter oilseed rape to the level of intensity of cultivation technology (in Polish). Rośliny Oleiste - Oilseed Crops, 24(1), 85-94. 